\title{
Bieruńskie „Genius loci” - szczególny przypadek miejsca węzłowego miasta
}

\author{
Grażyna Lasek
}

\author{
Instytut Architektury i Urbanistyki, Państwowa Wyższa Szkoła Zawodowa w Nysie
}

Streszczenie: W pracy zaprezentowano badania dotyczące analizy węzłów i punktów centralnych (knot) miasta Bieruń. Są nimi: kopiec, rynek, kościół pw. św. Walentego i plac św. Walentego. Można tutaj odnaleźć korzenie tożsamości społeczeństwa małego miasta i jego okolic.

Bieruń historycznie położony jest na Górnym Śląsku, a dokładnie na Ziemi Pszczyńskiej. W 1387 roku otrzymał prawa miejskie. O rozwoju osady zadecydowały m.in. uwarunkowania środowiskowe oraz gospodarcze.

Z historią istniejącego od początku XVI do początku XIX wieku Wielkiego Stawu Bieruńskiego oraz systemu rzek, potoków i małych stawów, wiążą się m.in. pozostałości zabytkowej Grobli oraz legendy o Utopcach - „stworokach bieruńskich”. Trwała obecność wspomnianych legend, podań, ich żywotność wśród - nie tylko dawnych - ale i współczesnych mieszkańców Bierunia i terenów przyległych, stoi u podstaw procesu wyłaniania się ludowej tożsamości w przestrzeni miasta. Niektóre z tych elementów wkomponowano w studnię miejską - zaprojektowaną i zrealizowaną na początku XXI wieku na bieruńskim rynku w miejscu nieistniejącej, historycznej studni. Tym samym wprowadzono w jedną z najważniejszych przestrzeni publicznych miasta - rynek - legendy i podania przekazywane z pokolenia na pokolenie. Wspomniana studnia stała się wyróżnikiem miejsca lokalizacji oraz nośnikiem informacji historycznych i kulturowych. Nie mamy tu zatem do czynienia ze zwykłym ozdobnikiem ale z materializacją idei wyrosłej z tkanki żywej społeczności. Jeszcze głębszym jej wyrazem jest umieszczony centralnie w przestrzeni rynku Pomnik Powstańców Śląskich, który na tej właśnie ziemi jest autentycznym wyrazem pamięci o poległych ojcach.

Drugi, nawet ważniejszy poziom tożsamości kulturowej stanowi tutejsza głęboka religijność i kult świętego Walentego. Uznanie świętego Walentego za patrona miasta oraz podniesienie kościółka dn. 13.02.2015 roku do godności Sanktuarium stanowiło jedynie sformalizowanie istniejących przekonań religijnych. W jego sąsiedztwie powstał plac św. Walentego z centralnie zlokalizowaną kolumną świętego, będący niejako przedłużeniem miejsca kultu, a stanowiący zarazem uobecnienie postaci patrona w przestrzeni miasta.

Wszystkie mogą być przykładem przekazu cząstki budującej tożsamość miasta. W 2016 roku Władze Miasta Bieruń podjęli uchwałę o utworzeniu Zespołu parków kulturowych. Nazwano je: „Park Kulturowy dla Obszaru Staromiejskiego” i „Park Kulturowy dla obszaru Grobli”.

Słowa kluczowe: Bieruń, węzły i punkty centralne miasta, kopiec, rynek, kościół pw. św. Walentego i plac św. Walentego. 


\section{Wprowadzenie}

Wyodrębnione przez Kevina Lyncha węzły i punkty centralne (knot) - analogicznie jak rejony i obszary (district), granice i krawędzie (Edge), drogi i przejścia (path) a także charakterystyczne punkty i dominanty (landmark) - wchodzą w skład pięciu grup zagadnieniowo-problemowych elementów fizjonomii miasta. Wszystkie współdecydują o jego obrazie. Z każdym z nich związane są współtworzące je wyróżniki krajobrazowe. Dla węzłów i punktów centralnych są to wyróżniki funkcjonalne i symboliczne. Zawierające się w nich treści będą określać i definiować nie tylko znaczenie, odbiór oraz rolę jaką pełnią poszczególne węzły i punkty centralne, ale także i to, czy w danym konkretnym przypadku możemy domniemywać że posiadany przez nie zespół cech posiada znamiona wyjątkowości, i czy w konsekwencji możliwe jest - a być może nawet wręcz konieczne - analizowanie ich w kategoriach przypadków szczególnych. Można zatem postawić następujące pytanie: czy węzły i punkty centralne zlokalizowane w Bieruniu i tworzące pewnego rodzaju swoistą całość (kompleks), charakteryzują się takim zespołem cech zawierających się we współtworzących je wyróżnikach krajobrazowych: funkcjonalnych oraz symbolicznych, który będzie przemawiał za możliwością rozpatrywania ich w kategoriach szczególnego przypadku miejsca węzłowego w mieście?

Aktualnie w tkance miejskiej ponad 600-letniego Bierunia położonego na Górnym Śląsku, a konkretnie na ziemi pszczyńskiej, wyraźnie czytelne są i zarazem wyróżniają się dwa węzły i punkty centralne. Pierwszym z nich jest rynek - główny plac miejski wraz z najstarszym tutejszym kościołem parafialnym pod wezwaniem św. Bartłomieja. Drugim - zabytkowy drewniany kościół pod wezwaniem św. Walentego, przy którym znajduje się cmentarz oraz sąsiadujący z nimi, współcześnie zrealizowany skwer (plac) św. Walentego z kolumną-Pomnikiem św. Walentego Patrona Miasta Bierunia. Obydwa miejsca - węzły (kościółek oraz rynek) - są oddalone od siebie o kilkaset metrów (ok. 250 - 300). Łączy je ulica Krakowska będąca jednym z głównych ciągów komunikacyjnych miasta. Wymieniona droga, na wskazanym odcinku swojego przebiegu, staje się dla nich pewnego rodzaju osią kompozycyjną opartą na linii prostej. Ze względu na historię miasteczka nie można pominąć istnienia w jego obrębie wczesnośredniowiecznego kopca będącego w przeszłości punktem centralnym gródka rozplanowanego u jego podnóża.

Wydaje się, że uprawnionym będzie postawienie następującej tezy: kopiec, rynek z kościołem parafialnym oraz kościół pod wezwaniem św. Walentego, wraz z cmentarzem i placem św. Walentego należą do najważniejszych, wyróżniających się węzłów i punktów centralnych Bierunia. Zarazem stanowią one pewnego rodzaju całość (kompleks), poprzez współtworzące je, właściwe i specyficzne dla nich wyróżniki krajobrazowe funkcjonalne oraz symboliczne, wpisane w urbanistykę, architekturę i detal. Mogą one być istotnym elementem przekazującym cząstkę budującą tożsamość miasta. W szczególności poprzez symbolikę oraz znak możliwe jest odnalezienie i odczytanie w ich strukturze funkcjonalno - przestrzennej korzeni tożsamości lokalnej społeczności. Można je rozpatrywać w kategoriach szczególnego przypadku miejsca węzłowego w mieście.

Przyjęto następującą metodę badawczą:

- Zdefiniowanie cech szczególnych, które posiadają znamiona wyjątkowości, zawierają się w wyróżnikach krajobrazowych: funkcjonalnych oraz symbolicznych, a także mogą przemawiać za możliwością traktowania węzłów i punktów centralnych Bierunia w kategoriach „Genius loci” - szczególnego przypadku miejsca węzłowego miasta. 
- Charakterystyka wskazanych węzłów i punktów centralnych oraz właściwych dla nich wyróżników krajobrazowych: funkcjonalnych i symbolicznych.

- Ocena omawianych zagadnień, podsumowanie i wnioski.

\section{Wyróżniki krajobrazowe funkcjonalne i symboliczne węzlów, i punktów centralnych miasta Bieruń}

Węzły i punkty centralne Bierunia: kopiec, rynek oraz kościół pod wezwaniem św. Walentego wraz ze cmentarzem i placem św. Walentego odgrywają w tkance miejskiej bardzo ważną rolę zarówno z punktu widzenia kontekstu planistyczno - urbanistycznego jak i pod względem materialnym. Założono, że zakres problemowy w którym możemy dla nich poszukiwać cech szczególnych, posiadających znamiona wyjątkowości i zarazem zawierających się w wyróżnikach krajobrazowych: funkcjonalnych oraz symbolicznych, można rozpatrywać w następujących płaszczyznach:

- Historycznej;

- Urbanistycznej;

- Środowiska naturalnego;

- Kulturowej;

- Symboliki i znaku.

Na początku charakterystyki omawianych przestrzeni należy zauważyć, że proces ich budowy (realizacji), funkcjonowania, możliwości wyrazistego odczytywania w tkance urbanistycznej oraz oddziaływania na otoczenie nie przebiegał w sposób ciągły a raczej jest pewnego rodzaju zmienną. Wyróżniające się obecnie węzły i punkty centralne miasteczka nie tylko wykształciły się w różnych okresach historycznych jego rozwoju, ale także na przestrzeni wieków odgrywały w nim zróżnicowaną rolę - zmieniało się ich znaczenie. Analizując je w kontekście m.in. ich czytelności oraz historii szczególnie istotne są niektóre wydarzenia, specyfika cech środowiska naturalnego oraz krajobrazu kulturowego.

Kopiec, który aktualnie znajduje się w obrębie granic administracyjnych Bierunia, jest najstarszym zabytkiem miasta. Pod względem historycznym był pewnego rodzaju pierwszym jego miejscem węzłowym. W okresie przed lokacją miasteczka w XIII wieku, jego rozwój poprzedza historia budowli ziemnej w formie sztucznie usypanego pagórka - kopca, obwarowanego rowami i będącego punktem centralnym gródka - wczesnośredniowiecznej osady, siedziby książęcego urzędnika i jego drużyny. Zarówno kopiec jak gródek zbudowane zostały przy głównym, prastarym szlaku komunikacyjnym i handlowym prowadzącym z Krakowa do Wrocławia, poprzez Oświęcim, bród na Wiśle, Bieruń, Mikołów, Gliwice i Opole. W sąsiedztwie Bierunia, otoczonego moczarami, przebiegał on przez bród na rzece Białej (obecnie rzece Mlecznej). Kopiec z gródkiem odgrywał ważną rolę gospodarczą. Był jednym z punktów kontroli ruchu handlowego w ziemi raciborskiej, placówką celną książęcą oraz miejscem targowym. Dał zalążek podgrodziu, które z kolei stało się zalążkiem miasta Bieruń, lokowanego w 1387 roku „na nowym polu” w oparciu o prawo niemieckie. Obecnie pagórek znajduje się na terenie prywatnej posesji przy skrzyżowaniu ulic Kopcowej i Kadłubowej. Posiada wysokość około 5 - 5,5m, podstawę w kształcie czworoboku z zaokrąglonymi narożnikami i wymiarami 24x32m, oraz prawie owalny wierzchołek wielkości około 12x18m. Szczyt wieńczy mała, murowana, barokowa kapliczka św. Jana Nepomucena. Niestety całość użytkowana jest okazjonalnie, np. w trakcie nabożeństw majowych. [3, 4, 5] 


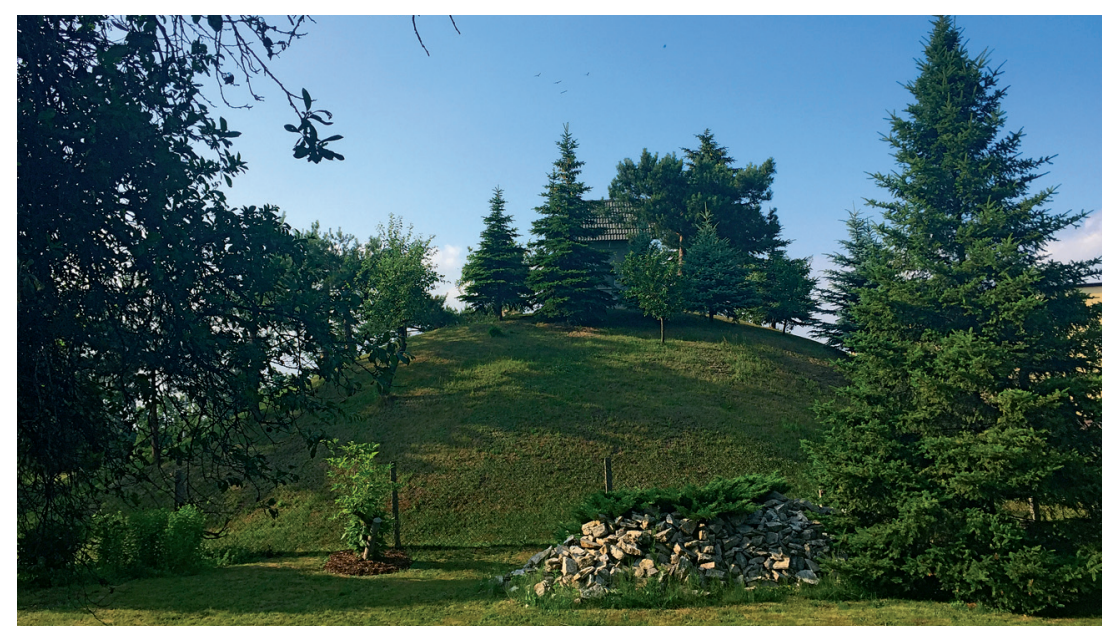

Fot. 1. Widok kopca w Bieruniu. Źródło: G. Lasek

Po lokacji Bierunia w rozplanowanym bardzo regularnym jego układzie urbanistycznym, typowym i charakterystycznym dla okresu średniowiecza, wyraźnie wrysowany jest kształt rynku. Ten główny ośrodek życia społecznego i gospodarczego miasta założony został na rzucie zbliżonym do kwadratu. Z każdego z naroży placu wyprowadzono po dwie ulice, usytuowane w stosunku do niego pod kątem prostym. W południowo-wschodnim narożniku rynku usytuowany jest orientowany rzymskokatolicki kościół parafialny pod wezwaniem św. Bartłomieja Apostoła. Pierwsza znana wzmianka, z której wynika, że kościół ten już istnieje pochodzi z 1441 roku. Początkowo był to obiekt drewniany, od drugiej połowy XVIII wieku - murowany. Przebiegająca obok kościoła ul. Krakowska przecina po przekątnej płytę rynku. Prowadzona jest w kierunkach północno-zachodnim oraz południowo-wschodnim, co zarazem pokrywa się z kierunkami najsilniejszego rozwoju tkanki miejskiej. Od wieków na jej kształt bardzo mocno wpływały cechy krajobrazu. Niektóre z nich były naturalnymi barierami rozwojowymi, z kolei inne zostały utworzone przez człowieka w sposób sztuczny. Spośród czynników naturalnych należy wskazać przede wszystkim na ukształtowanie terenu, rozległe obszary podmokłe które niemalże otaczały miasto, sieć rzek i potoków oraz liczne, naturalne zbiorniki wodne. To właśnie specyfika elementów środowiska naturalnego wraz z bardzo dobrą późnośredniowieczną koniunkturą gospodarczą wpłynęły na podjęcie przez władze miasta oraz księcia pszczyńskiego decyzji o budowie w latach 1530-1549 Wielkiego Stawu Bieruńskiego zwanego także „Jeziorem Bieruńskim”. Zbiornik w okresie swojej największej świetności zajmował powierzchnię około 600-625 hektarów. Hodowano w nim ryby. Jeszcze w XVI wieku, w trakcie szeroko zakrojonych prac inżynieryjnych, usypano groblę. Jest to wał ziemny istniejący do dzisiaj w znacznej swojej części i zlokalizowany od strony wschodniej miasta. Zabezpieczał on tkankę urbanistyczną przed powodzią, której źródłem zagrożenia była obecność „Jeziora Bieruńskiego” oraz ułatwiał spiętrzanie wód w zbiorniku. W sumie przemysł rybny w okolicy Bierunia rozwijał się aż do przełomu XVIII -XIX wieku, kiedy to nastąpiło załamanie się dotychczasowej koniunktury gospodarczej. Na początku XIX wieku osuszono Wielki Staw Bieruński. Zaczęto rozwijać rolnictwo, zbudowano folwark, wytyczono układ pól i łąk $[3,4,5]$. Spośród pozostałych barier dla kierunków rozwojowych urbanistyki Bierunia należy także wskazać na nieuregulowany w przeszłości bieg rzeki Mlecznej (dawniej rzeki Białej), opływającej miasto od strony zachodniej. 


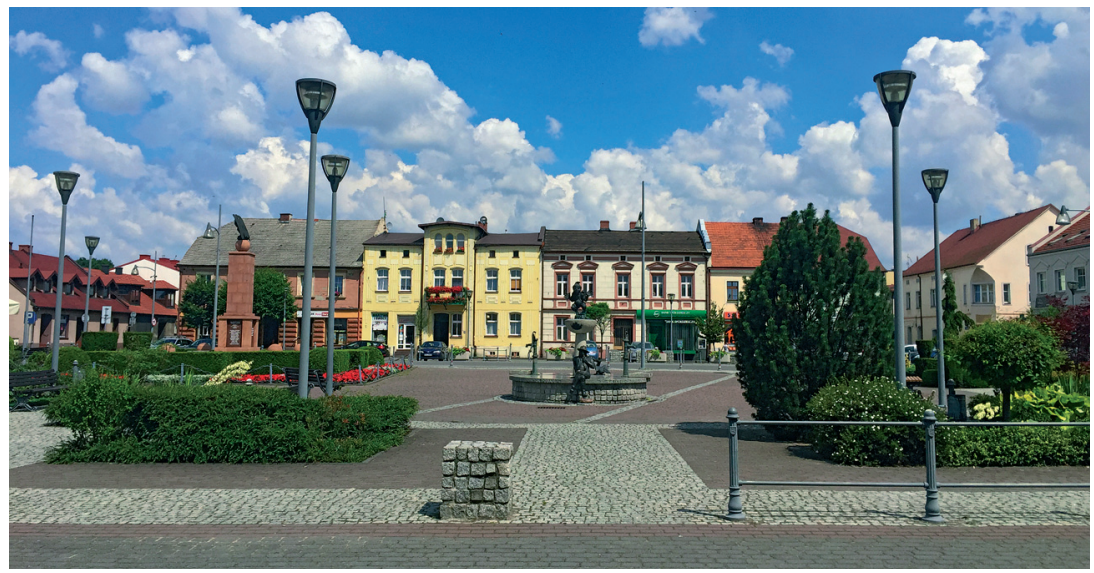

Fot. 2. Widok rynku w Bieruniu. Źródło: G. Lasek

Kierując się z rynku w stronę południowo-wschodnią i zarazem podążając wyżej wymienioną ul. Krakowską, w odległości kilkuset metrów od płyty głównego ośrodka życia społecznego i gospodarczego zlokalizowane jest kolejne bardzo ważne miejsce kulturowe Bierunia. Stanowi go zabytkowy kościół pod wezwaniem św. Walentego, drewniany, o konstrukcji wieńcowej, wraz z cmentarzem oraz sąsiadującym, współcześnie zaprojektowanym i zrealizowanym skwerem (placem) św. Walentego, z kolumną - pomnikiem św. Walentego Patrona Miasta Bierunia. W przypadku obiektu sakralnego nie znamy daty jego powstania. Pierwsza historyczna wzmianka pochodzi z 1628 roku. Skwer lub tzw. plac św. Walentego zbudowano w 2008 roku. Autorami projektu są: mgr art. plastyk Roman Nyga, mgr art. rzeźbiarz Stanisław Hochuł, mgr inż. arch. Michał Kuczmiński oraz dr inż. arch. Grażyna Lasek. [3, 4, 5]

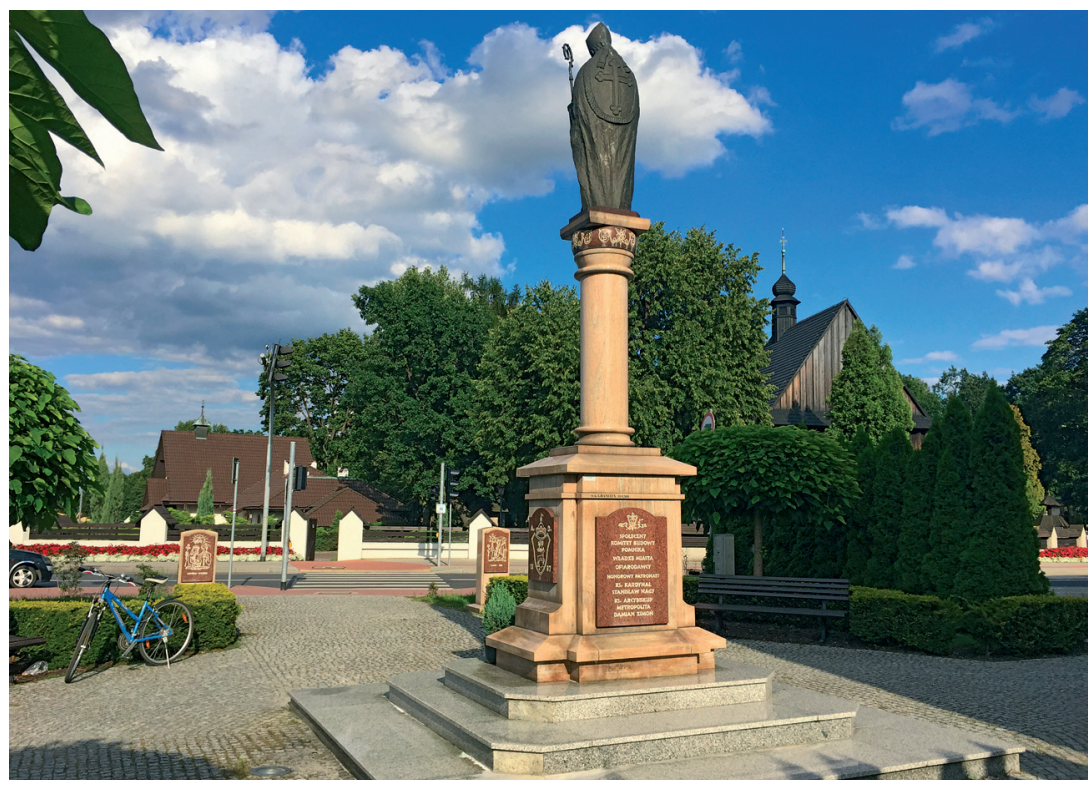

Fot. 3. Widok kościoła p.w. św. Walentego oraz placu św. Walentego. Źródło: G. Lasek 
Wszystkie, wyżej wymienione węzły i punkty centralne miasta zlokalizowane są w obrębie Parku Kulturowego dla Obszaru Staromiejskiego, który z kolei wraz z Parkiem Kulturowym dla Obszaru Grobli współtworzy Zespół parków kulturowych, utworzony w Bieruniu w 2016 roku. Główny plac miejski wchodzi także w skład zabytkowego układu urbanistycznego. $[1,2]$ Zarazem należy podkreślić, że współcześnie tylko rynek i kompleks sakralny są intensywnie użytkowane przez mieszkańców i turystów.

Kolejnym aspektem analiz bieruńskich „Genius loci” jest sposób wpisania ich w architekturę oraz detal.

Rynek jest wnętrzem urbanistycznym dla którego ścianami są pierzeje kamienic, których obecny kształt pochodzi w przeważającej części z II połowy XIX wieku (poprzednia zabudowa, głównie drewniana, spłonęła w połowie XIX wieku). Najważniejszymi składowymi współtworzącymi płytę placu i zarazem współdecydującymi o jego charakterze są zlokalizowane na nim obiekty małej architektury: Pomnik Powstańców Śląskich, studnia miejska, kamień milowy DK $441495 \mathrm{~km}$, murki, pamiątkowe płyty z herbami miast partnerskich oraz zegar słoneczny zbudowany w miejscu, w którym do 1845 roku istniał Budynek Wagi Miejskiej. W szczególności w strukturze architektoniczno-plastycznej i funkcjonalno-przestrzennej dwóch spośród nich, a mianowicie w pomniku Powstańców Śląskich oraz w studni miejskiej, poprzez symbolikę i znak możliwe jest odnalezienie i odczytanie elementów dopełniających i dookreślających przestrzeń miejsca ich zlokalizowania. W pierwszym przypadku są nimi treści rodzinne i patriotyczne, w drugim - podaniowe oraz ludowe.

Pomnik Powstańców Śląskich zlokalizowany jest w centralnym miejscu płyty rynku. Jego historia sięga okresu międzywojennego XX wieku. Upamiętnia trzy wystąpienia zbrojne ludności śląskiej przeciwko władzom niemieckim. Po zniszczeniu, któremu uległ w trakcie II wojny światowej został wprawdzie odbudowany, ale w zmienionej formie. Pierwotny kształt przywrócono mu dopiero w 2004 roku, w trakcie działań rewitalizacyjnych placu prowadzonych w latach 2004-2005. [7] Integralną częścią Pomnika jest wieńcząca go rzeźba orła a także pamiątkowe tablice czczące ofiary II wojny światowej umieszczone na cokole. Można powiedzieć, że właśnie ten obiekt małej architektury zbudowany na ziemi śląskiej jest autentycznym wyrazem pamięci o poległych ojcach oraz zmaterializowanym przedstawieniem idei wyrosłej z tkanki żywej społeczności. W tym kontekście koniecznie należy podkreślić fakt, że pomnik ten powstał na miejscu pierwotnego ratusza miejskiego, którego lokalizację zmieniono w XIX wieku, podczas odbudowy miasta po pożarze. [4]

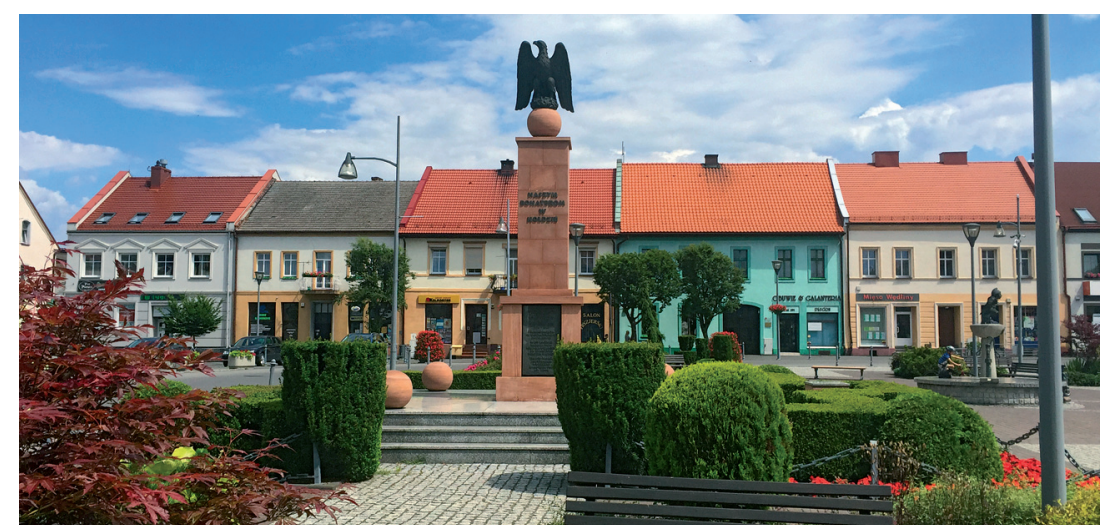

Fot. 4. Widok Pomnika Powstańców Śląskich zlokalizowanego na płycie rynku w Bieruniu. Źródło: G. Lasek 
Z kolei studnia miejska jest obiektem zaprojektowanym wprawdzie także na początku XXI wieku, ale zarazem zrealizowanym w miejscu dawnej, historycznej studni, pochodzącej prawdopodobnie z okresu powstania rynku. Posiada bardzo charakterystyczną przyciągającą uwagę formę, która w sposób istotny przyczynia się do tego, że to właśnie wokół niej najczęściej gromadzą się ludzie. Wkomponowano w nią rzeźby przedstawiające utopca - będącego najpopularniejszym tzw. „,bieruńskim stworokiem”. Utopce współtworzyły grupę lokalnie występujących postaci - duchów, obecnych w sferze tutejszych ludowych podań i legend. Informacje o nich przekazywano z pokolenia na pokolenie. Ze względu na to, że rewiry występowania utopca obejmowały podmokłe tereny okalające w przeszłości miasto Bieruń, okolice kopca oraz rejon Wielkiego Stawu Bieruńskiego, można powiedzieć, że postacie te oprócz aspektów kulturowych mogą przywoływać w ludzkiej pamięci również nieistniejące już lub w znacznym stopniu zdegradowane dziś cechy dawnego środowiska i krajobrazu naturalnego oraz funkcjonowania społecznego. - Utoplec spotykał samotnych mieszkańców na podmokłej łące, brzegu rzeki lub stawu, zagajał, zamieniał się z nimi na fajkę która okazywała się następnego dnia gałązką, zabierał buty, płacił opadłymi liśćmi, wodził po łąkach wracających z pracy itp. [6] W konsekwencji możliwe jest zatem odczytanie studni miejskiej w kategoriach elementu, który w przestrzeni miejsca swojego zlokalizowania staje się materialnym wyrazem ludowej tożsamości mieszkańców Bierunia i terenów przyległych.

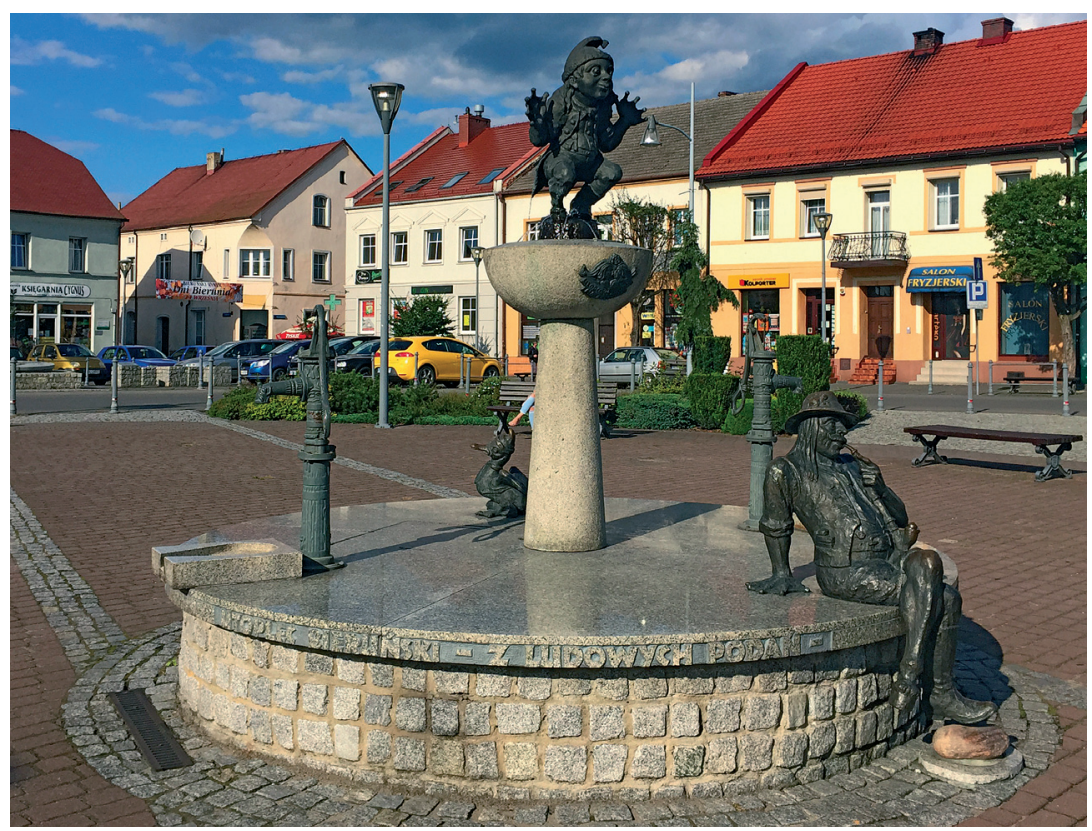

Fot. 5. Widok studni miejskiej zlokalizowanej na płycie rynku w Bieruniu. Źródło: G. Lasek

Zarówno w przypadku Pomnika Powstańców Śląskich jak i studni autorami projektów są: mgr art. plastyk Roman Nyga, mgr art. rzeźbiarz Stanisław Hochuł, mgr inż. Marek Skałkowski oraz mgr inż. arch. Grażyna Lasek.

W przypadku kompleksu sakralnego zlokalizowanego wokół kościoła św. Walentego mamy do czynienia z przekazem ważniejszego poziomu tożsamości kulturowej, którą stanowi tutejsza głęboka religijność i kult świętego Walentego. XVI-wieczny drewniany ko- 
ściół świętego Walentego skupiał przez wieki i nadal zrzesza ogromną liczbę wiernych i wyznawców, zarówno z samego Bierunia jak i okolic, ciesząc się sławą miejsca licznych uzdrowień oraz błogosławieństwa stanu narzeczeńskiego. Ustanowienie przez Kongregację do Spraw Kultu Bożego i Dyscypliny Sakramentów św. Walentego, biskupa i męczennika, patronem miasta Bierunia, które nastąpiło 20 grudnia 2003 roku, następnie przekazanie aktu nadania w dniu 13 lutego 2004 roku oraz podniesienie kościoła św. Walentego do godności Sanktuarium św. Walentego w dniu 13.02.2015 roku - stanowiło jedynie sformalizowanie istniejących przekonań religijnych [8]. Wyjątkowe w swej istocie wydarzenia stały się przyczynkiem do tego, że w 2008 roku w sąsiedztwie kościoła pod wezwaniem św. Walentego zbudowano skwer - tzw. plac św. Walentego z centralnie zlokalizowaną kolumną - Pomnikiem św. Walentego Patrona Miasta Bierunia. Jest on poniekąd przedłużeniem miejsca kultu stanowiącym zarazem uobecnienie postaci patrona w przestrzeni miasta i szczególnym sposobem wyrażenia przez mieszkańców swojej wdzięczności. Główne dojście do centralnego punktu placu flankowane jest dwoma niewysokimi cokołami, na których po obydwu stronach umieszczono granitowe płyty z rysunkami oraz podpisami: „miłość - czystość”, „czyńmy dobro”, „wiara - modlitwa”, „łaska - cud”. Tym samym dodatkowo nawiązano jeszcze do wartości i cech związanych z postacią św. Walentego. Na uwagę zasługuje także fakt, że plac z pomnikiem powstał dzięki zabiegom Stowarzyszenia Miłośników 600-letniego Bierunia, wsparciu ówczesnych władz miasta, organizacji społecznych i mieszkańców. [8]

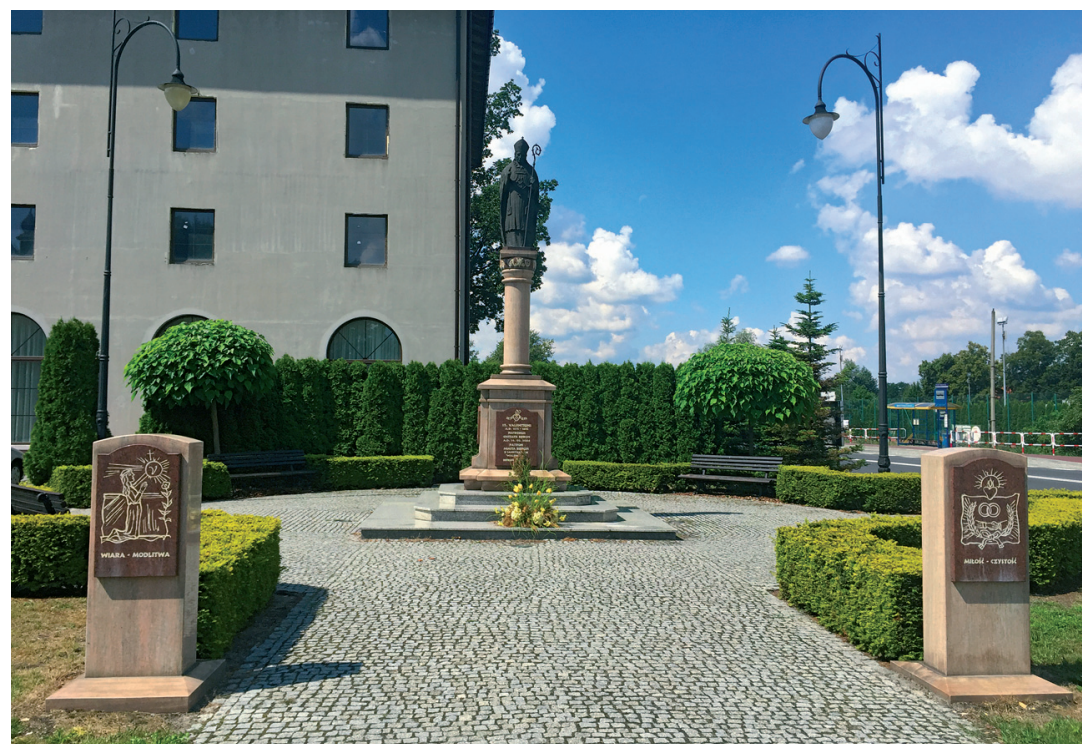

Fot. 6. Widok placu św. Walentego - kolumny oraz tablic. Źródło: G. Lasek

\section{Podsumowanie i wnioski}

W oparciu o zrealizowane badania należy stwierdzić, że w ponad 600 - letnim mieście Bieruń najważniejsze i wyróżniające się węzły i punkty centralne którymi są: kopiec, rynek z kościołem parafialnym oraz kompleks sakralny składający się z kościoła pod wezwaniem św. Walentego przy cmentarzu oraz z sąsiadującego z nimi skweru - placu św. Walentego, 
tworzą pewnego rodzaju swoistą całość. Wszystkie charakteryzują się takim zespołem cech, zawierających się we współtworzących je wyróżnikach krajobrazowych funkcjonalnych i symbolicznych, który wskazuje na możliwość rozpatrywania ich w kategoriach szczególnego przypadku miejsca węzłowego w mieście - „Ducha miejsca” - „Genius loci” miasta Bieruń. Poprzez symbolikę i znak, wpisane w urbanistykę, architekturę oraz detal, można odnaleźć i odczytać w ich strukturze funkcjonalno-przestrzennej korzenie tożsamości tutejszego społeczeństwa - zarówno samego miasteczka, jak i jego okolic. Architektura i sztuka będące narzędziem wyrazu tej tożsamości stają się nośnikami symboli i znaków wiary, legendy i krajobrazu tutejszej ziemi. Ty samym mogą być materialnym środkiem przekazu treści ważnych, istotnych dla człowieka, z którymi społeczność lokalna identyfikuje się i może się w przyszłości identyfikować.

\title{
Literatura
}

[1] Uchwata nr III/6/2016 Rady Miejskiej w Bieruniu z dnia 31 marce 2016 r. w sprawie utworzenia Zespołu parków kulturowych pod nazwami Park Kulturowy dla Obszaru Staromiejskiego i Park Kulturowy dla Obszaru Grobli, Dziennik Urzędowy Województwa Śląskiego, Katowice, dnia 18 kwietnia 2016r. Poz. 2285.

[2] Uchwata $n r$ III/7/2016 Rady Miejskiej w Bieruniu z dnia 31 marca 2016r, w sprawie zatwierdzenia Planu ochrony Zespołu parków kulturowych pod nazwa Park Kulturowy dla Obszaru Staromiejskiego i Park Kulturowy dla Obszaru Grobli. Dziennik Urzędowy Województwa Śląskiego, Katowice, dnia 18 kwietnia 2016r. Poz. 2286.

[3] Lysko A., Nyga R. Z przeszłości 600-letniego Bierunia. Zeszyty bieruńskie, zeszyt 1, Bieruń.

[4] Musioł L. BIERUŃ miasto kościót i parafia. Monografia historyczna. Bieruński Ośrodek Kultury, Bieruń 1999. („Książkę wydano na podstawie maszynopisu z 1953 roku znajdującego się w Parafii św. Bartłomieja oraz maszynopisu z Oddziału Zbiorów Specjalnych Biblioteki Śląskiej w Katowicach (Sygnatura R 851 III uzupełnionych przez autora w 1970 roku”, s. 4).

[5] Nyga J. Pamiątki przeszłości Bierunia. Zabudowa miejska. Kopiec. Grobel, Zeszyty bieruńskie, zeszyt 11, Bierun.

[6] Nyga R., Zaczyk E., Nyga J. Stwôrôki. Wizerunki stworoków śląskich, Bieruński Ośrodek Kultury, Bieruń 1994.

[7] www.polskaniezwykła.pl>web>place (14.06.2017).

[8] www.bierun.pl/miasto_bierun/kosciol_sw_walentego.html (14.06.2017).

\section{Bierun's genius loci (spirit of the place) - a special case of a city junction}

\section{Grażyna Lasek}

Institute of Architecture and Urban Planning, University of Applied Sciences in Nysa

\begin{abstract}
The publication presents analysis of the knots and focal points (knots) of the city Bieruń. They are: mound, Town Square with St. Bartolomeus church, St. Valentine's church and St. Valentine's Square. This is where we can find the roots of identity of society living in a small town and its surroundings.
\end{abstract}


Historically, Bierun is located in Upper Silesia and Pszczyna region. Bierun was given municipal rights in 1387. The settlement started developing because of environmental conditions and economical conditions.

The history of existing from the beginning of 16th until the beginning of 19th century, the Great Pond of Bierun, rivers, streams and small ponds is connected with residues of monumental dike as well as the legends of the Drowners - Bierun's creatures. The presence of mentioned legends among previous and modern citizens of Bierun is the basis of a process creating country awareness in town's area. Some of those elements are incorporated in city's well - designed and made in the beginning of 21 st century in the town's market where historical well was located. This means that legends passed on from generation to generation became part of the most important area of the town. The well became an important indicator of historical and cultural information. Besides being just a simple decorative element, it is a materialization of an idea based on living society. The Silesian Insurgents> Monument placed in the middle of town's market is even greater example of living society, as in this area it is a true example of society's memory of their killed fathers.

The second, perhaps even more important level of cultural identity is local deep faith and cult of St. Valentine. It is a famous place of many miraculous recoveries as well as fiancés blessing. Recognizing St. Valentine as a patron saint of the town and the church as a sanctuary in 2015 was a proof of existing religious belief. In the vicinity of the church, authorities created St. Valentine's square with his sculpture being an extension of the place of cult and a sign of patron saint presence in the town's area.

All they might be an example of an idea transfer, that creates town's identity. In 2016 Bierun's authorities undertook a decision of creating a set of cultural parks. They were named: "Cultural park for Old Town area" and "Cultural park for dike area".

Keywords: Bierun, knots and focal points (knots), mound, Town Square, church. St. Valentine's Day and Square St. Valentine. 